\title{
Synthesis and Biological Evaluation Study of New Bis- imine Ligand and Metal Complexes
}

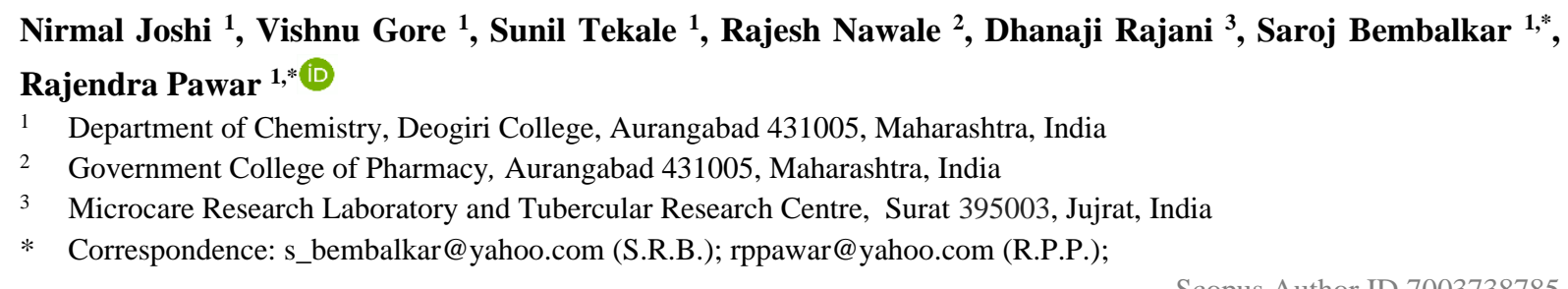

Received: 30.09.2020; Revised: 20.10.2020; Accepted: 21.10.2020; Published: 25.10.2020

Abstract: A new Schiff base bis-imine ligand was synthesized by the reaction of 1-(2-bromo, 5methoxy benzylidene) hydrazine and 5-chlorosalicylaldehyde. This bis-imine ligand was used for the synthesis of metal complexes. The synthesized ligand and metal complexes were characterized by spectroscopic techniques. The metal complexes were formed in the ligand to metal ratio of 2:1. The synthesized metal complexes were screened for antimalarial, anti-tubercular, and antimicrobial activities.

Keywords: bis-imine; metal complexes; anti-malarial; anti-tubercular; anti-microbial activities.

(C) 2020 by the authors. This article is an open-access article distributed under the terms and conditions of the Creative Commons Attribution (CC BY) license (https://creativecommons.org/licenses/by/4.0/).

\section{Introduction}

Schiff bases contain the $\mathrm{C}=\mathrm{N}$ functional group and are an important class of compounds as they are used for the synthesis of biologically active heterocyclic compounds [1]. Schiff bases are used as chelates for complexation with metal ions [2]. Schiff base ligands containing nitrogen and oxygen donor atoms can form complexes with metal ions [3]. Imines are vital because of their stability and biological activity. Schiff base ligands and their metal complexes showed anti-depressant, anti-inflammatory, anticonvulsant, antimicrobial, anti-tubercular, antimalarial, and anti-viral activities [4-5].

Many bioactive compounds used in agricultural, material science, medicinal and pharmaceutical fields can be synthesized from bis-imines [6]. Some metal complexes of bisimines are used as catalysts in organic reactions [7]. Cobalt (II) and iron (III) complexes of pyridine bisimine ligands showed activity in the polymerization of ethylene.

In continuation of our work in the synthesis and biological activity of Schiff base ligand and metal complexes [8-10], we report the synthesis of Schiff base (bis-imine) ligand from 1(2-bromo, 5-methoxy benzylidene) hydrazine and 5-chlorosalicylaldehyde. The synthesized ligand was used for the synthesis of metal complexes. The synthesized compound was characterized by different spectroscopic methods, and metal complexes were evaluated for antimalarial, anti-tubercular, and antimicrobial activities. 


\section{Materials and Methods}

All the chemicals used for the synthesis were of analytical grade. Distilled solvents were used [11].

\subsection{Synthesis of [1-(2-bromo, 5-methoxy benzylidene) hydrazine]-.}

2-bromo, 5-methoxy benzaldehyde (1) (1 mmol), and hydrazine hydrate (2) (7 -8mmol) were dissolved in solvent ethanol, and 1-2 drops of concentrated sulphuric acid were added as a catalyst. The resulting reaction mixture was refluxed for 4 hours at $80^{\circ} \mathrm{C}$, and the progress of the reaction was monitored by TLC. After completion of the reaction, the reaction mixture was cooled, and the product was precipitated by the addition of ice. The product 1-(2-bromo, 5methoxy benzylidene) hydrazine (3) was recrystallized from ethanol and confirmed by melting point and IR spectra (Scheme 1). Melting point $=161^{\circ} \mathrm{C}$, color: yellow, solid. IR spectra- IR (FTIR-ATR, $\left.v_{\max } \mathrm{cm}^{-1}\right): 1620(\mathrm{C}=\mathrm{N}), 3045(\mathrm{NH})$.

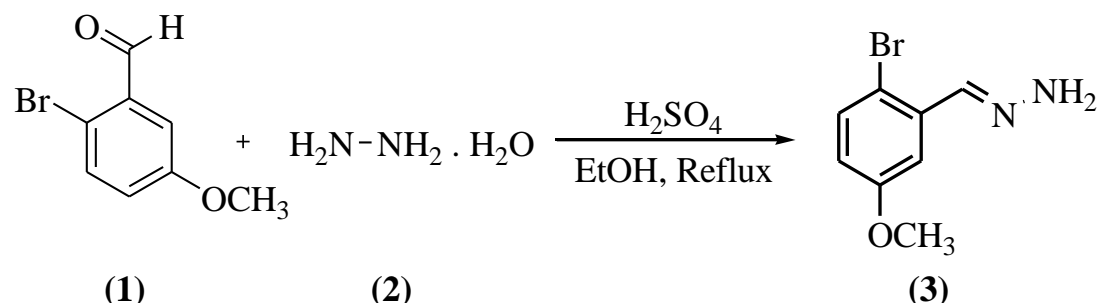

Scheme 1. Synthesis of 1-(2-bromo, 5-methoxy benzylidene) hydrazine.

\subsection{Synthesis of Schiff base ligand (Bis-imine) (SB).}

$1 \mathrm{mmol}$ of 5-chlorosalicyladehyde (4) was added to $1 \mathrm{mmol}$ of 1-(2-bromo, 5-methoxy benzylidene) hydrazine (3) in solvent ethanol, and 1-2 drops of concentrated sulphuric acid were added as a catalyst. The mixture was refluxed for 3-4 $\mathrm{hr}$ at $80^{\circ} \mathrm{C}$. The progress of the reaction was monitored by TLC. After completion of the reaction, the reaction mixture was cooled, and the product was precipitated by the addition of ice. The solid product was filtered out, washed with cold water, dried, and recrystallized from ethanol. The product was confirmed by IR spectra as pure Schiff base ligand (bis-imine) (Scheme 2).

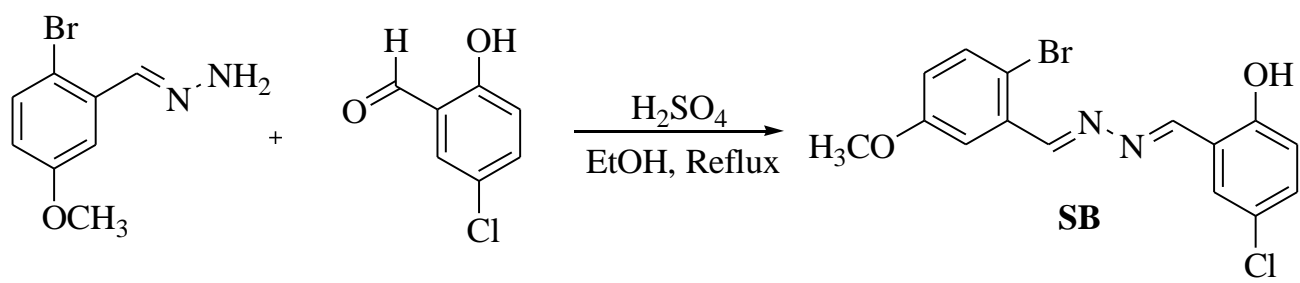

Scheme 2. Synthesis of Schiff base ligand (bis-imine) (SB).

IR spectra of bis-imine Ligand (SB)-: $\left(v_{\max } \mathrm{cm}^{-1}\right) 1616(\mathrm{C}=\mathrm{N})$.

\subsection{Synthesis of metal complexes (SB1-8).}

A mixture of metal salt (metal chlorides/metal nitrates) and Schiff base bis-imine ligand (SB) in solvent ethanol was prepared. The ratio of metal to the ligand in mmol was 1:2. Few drops of ammonia were added to the mixture. The mixture was refluxed for 5-6 hr. The progress of the reaction was monitored by TLC. The products were cooled, filtered out, and dried. Melting points of the products were determined (Scheme 3). 


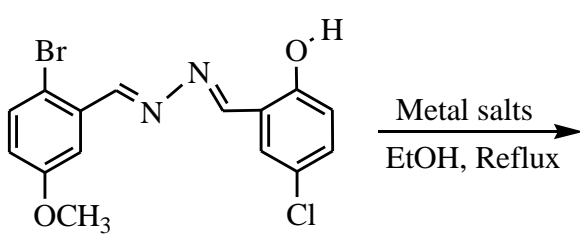

Schiff's base

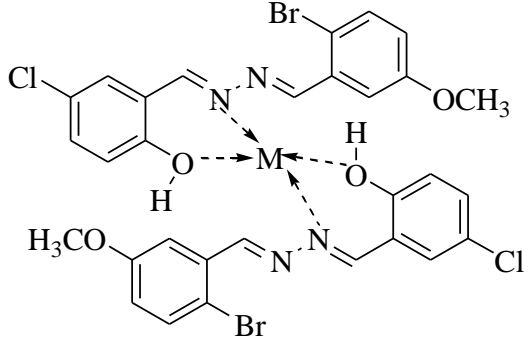

$\mathrm{M}=\mathrm{Zn}(\mathrm{II}), \mathrm{Fe}$ (II),Ni(II), Sn(II), Cu(II), Cd(II), Cr(II) and Zr(II)

Scheme 3. Synthesis of metal complexes (SB1-8).

The physical and analytical data of synthesized compounds are presented in Table 1.

\subsection{Infrared spectra of metal complexes.}

The IR spectra of metal complexes were recorded in the wave number region of $250 \mathrm{~cm}^{-1}-4500 \mathrm{~cm}^{-1}$ [12]. The characteristic spectral band in the region $395-462 \mathrm{~cm}^{-1}$ indicates the $\mathrm{M}-\mathrm{N}$ band frequency i.e., the coordination of metal ion with the nitrogen atom of the ligand. The low-frequency band in the region $500-827 \mathrm{~cm}^{-1}$ was characterized for metal complexes and indicates the coordination of oxygen atom of the ligand with metal, i.e., M-O frequency bands. The frequency bands at $1610-1624 \mathrm{~cm}^{-1}$ can be recognized for $\mathrm{C}=\mathrm{N}$ group. The stretching frequency bands at 2939-3074 $\mathrm{cm}^{-1}$ were assigned for $\mathrm{C}-\mathrm{H}$ bond. IR spectra for metal complexes are reported in Table 2.

\subsection{UV -Visible spectra of metal complexes.}

UV spectra of synthesized metal complexes was recorded in DMSO solvent. The wavelength of maximum absorbance $\left(\lambda_{\max }\right)$ for metal complexes is reported in Table 3.

\subsection{Biological activity}

\subsubsection{Antimalarial activity.}

Newly synthesized metal complexes were screened for antimalarial activities. The invitro antimalarial analysis was performed in 96 well microtitre plates, as stated by Rieckmann and co-workers in the microassay protocol with minor changes. The in-vitro assay was performed to determine the susceptibility of Plasmodium falciparum to antimalarial metal complexes/compounds. P. Falciparum strain cultures were preserved in RPMI 1640 medium supplemented with $0.23 \%$ sodium bicarbonate, $10 \%$ heat-inactivated human serum, $25 \mathrm{mM}$ HEPES and $1 \%$ D-glucose. The parasites of $P$. Falciparum were synchronized by the treatment with $5 \%$ D-sorbitol to have only ring stage parasitized cells. DMSO solvent was used to prepare $5 \mathrm{mg} / \mathrm{mL}$ as a stock solution of each of the test compounds, and successive dilutions were prepared with a culture medium. The diluted samples containing parasitized cells in $20 \mu \mathrm{L}$ volume were added to the test wells so as to get concentrations in the range $0.4 \mu \mathrm{g} / \mathrm{mL}$ to 100 $\mu \mathrm{g} / \mathrm{mL}$ in duplicate well. At $37^{\circ} \mathrm{C}$, in a candle jar, the culture plates were incubated for 36 to 40h. After incubation, thin blood smears from each well were made and then stained with JSB (Jaswant Singh Bhattacharya) staining. The slides were studied microscopically, and the growth of ring-stage parasites into trophozoites and schizonts was noted in the presence of test compounds of different concentrations. The minimum concentration of the test compound, 
which inhibits the full growth of parasite into schizonts, was reported as the Minimum Inhibitory Concentration (MIC) [13].

Standard drugs used were Chloroquine and Quinine. The antimalarial activity of synthesized metal complexes is given in Table 4 .

\subsubsection{Anti-tubercular activity.}

The MIC (Minimal Inhibition Concentration) is one of the most well-known methods to assess anti-tubercular activity. It is non-automated in-vitro bacterial susceptibility tests carried out in the bottle. MIC is the lowest concentration of the test compound required to inhibit the growth of the microorganisms, while growth is defined as 20 colonies or more. This method is simple and is carried out with a test compound containing slope, whereas it is desirable to use more than one slope. Metal complexes were evaluated against the H37Rv strain (Mycobacterium tuberculosis). L.J. (Lowenstein-Jensen) medium was used as a nutrient medium to grow microbes and to dilute the test sample suspension. Inoculum size $1 \mathrm{mg} / \mathrm{mL}$ for test strain was maintained [14].

DMSO was used as diluents to prepare different concentrations of test compounds. A stock solution of 2000 microgram $/ \mathrm{mL}$ of each synthesized metal complex was prepared.

In primary evaluation, $500 \mu \mathrm{g} / \mathrm{mL}, 250 \mu \mathrm{g} / \mathrm{mL}$, and $125 \mu \mathrm{g} / \mathrm{mL}$ concentrations of the synthesized compounds were taken. In this primary evaluation, the synthesized compounds found active were further tested in secondary evaluation. For secondary evaluation, the synthesized compounds found active in primary evaluation were diluted to get $100 \mu \mathrm{g} / \mathrm{mL}$, $50 \mu \mathrm{g} / \mathrm{mL}, 25 \mu \mathrm{g} / \mathrm{mL}, 12.5 \mu \mathrm{g} / \mathrm{mL}, 6.250 \mu \mathrm{g} / \mathrm{mL}, 3.125 \mu \mathrm{g} / \mathrm{mL}$ and $1.5625 \mu \mathrm{g} / \mathrm{mL}$ concentrations. The least concentration showing at least $99 \%$ inhibition is reported as MIC.

Isoniazid and Rifampicin were used as standard drugs. The MIC values of synthesized compounds were compared with standard drugs, as presented in Table 5.

\subsubsection{Antimicrobial activity.}

For antimicrobial activity, Broth Dilution Method was applied. It is a non-automated, in-vitro microbial susceptibility test. It is performed in tubes. Synthesized metal complexes were analyzed against three fungi C. Albicans (MTCC 227), A. Niger ( MTCC 282) and A. Clavatus ( MTCC 1323), and four bacteria species E. Coli (MTCC 443), P. Aeruginosa (MTCC 1688), S. Aureus (MTCC 96) and S. Pyogenus (MTCC 442). The Nutrient Medium employed to grow microbes and to dilute the test compound suspension for the test microbes was Mueller Hinton Broth.

The size of the inoculum for test strain was fixed to $10^{8}$ Colony Forming Unit (CFU) $/ \mathrm{mL}$ by analyzing the turbidity. DMSO solvent was used in the preparation of solutions of metal complexes. DMSO solution (without compound) was used as control.

Broth Dilution Method can be used for the determination of MIC (Minimal Inhibition Concentration). The control tube is subcultured with a medium useful for the growth of the test microorganism and incubated overnight at $37^{\circ} \mathrm{C}$. A stock solution of $2000 \mu \mathrm{g} / \mathrm{mL}$ concentration of each synthesized metal complex was prepared. For primary and secondary evaluation of metal complex, serial dilutions were prepared. 1000 microgram $/ \mathrm{mL}, 500$ microgram $/ \mathrm{mL}$, and $250 \mathrm{microgram} / \mathrm{ml}$ concentrations of the synthesized metal complexes were used in the primary evaluation. The synthesized metal complexes found active in the primary evaluation were taken for secondary evaluation against microorganisms. In secondary evaluation, the metal 
complexes which were active in primary evaluation were diluted to get 200 microgram $/ \mathrm{mL}$, $100 \mathrm{microgram} / \mathrm{mL}, 50 \mathrm{microgram} / \mathrm{mL}, 25 \mathrm{microgram} / \mathrm{mL}, 12.5$ microgram $/ \mathrm{mL}$, and 6.25 microgram $/ \mathrm{mL}$ concentrations.

The Minimal Inhibition Concentration of the control microorganism is recorded to check the reliability of the concentration of the metal complex. The minimum concentration showing at least $99 \%$ inhibition zone is recorded as MIC.

The MIC for newly synthesized metal complexes were compared with standard drugs for fungi (Nystatin and Greseofulvin) and standard drugs for bacteria (Ampicillin, Chloramphenicol, Gentamycin, Ciprofloxacin, and Norfloxacin) as reported in Table 6.

\section{Results and Discussion}

The bis-imine ligand (SB) was prepared by the reaction of 5-chlorosalicyaldehyde with synthesized 1-(2-bromo, 5-methoxy benzylidene) hydrazine. Metal complexes were synthesized from Schiff base bis-imine ligand. Synthesized ligand and metal complexes were characterized by different spectroscopic methods.

Table 1. Physical and analytical data of the synthesized compound.

\begin{tabular}{|c|c|c|c|c|c|c|c|c|}
\hline \multirow[t]{2}{*}{$\begin{array}{l}\text { Sample } \\
\text { Code }\end{array}$} & \multirow[t]{2}{*}{ Compound } & \multirow[t]{2}{*}{ M.F. (F.W.) } & \multirow[t]{2}{*}{ M. P. $\left({ }^{\circ} \mathrm{C}\right)$} & \multirow[t]{2}{*}{ Color } & \multicolumn{4}{|c|}{$\begin{array}{l}\text { Elemental } \\
\text { Calculated }\end{array}$} \\
\hline & & & & & $\mathrm{C}$ & $\mathrm{H}$ & $\mathrm{N}$ & $\mathrm{M}$ \\
\hline SB & Ligand(L) & $\begin{array}{l}\mathrm{C}_{15} \mathrm{H}_{12} \mathrm{~N}_{2} \mathrm{O}_{2} \mathrm{BrCl} \\
(367.5)\end{array}$ & 220 & Yellow & 48.97 & 3.26 & 7.61 & - \\
\hline SB1 & $\mathrm{CuL}_{2}$ & $\begin{array}{l}\mathrm{C}_{30} \mathrm{H}_{24} \mathrm{~N}_{4} \mathrm{O}_{4} \mathrm{Br}_{2} \mathrm{Cl}_{2} \mathrm{Cu} \\
(798.54)\end{array}$ & $>300$ & $\begin{array}{l}\text { Yellowish } \\
\text { Brown }\end{array}$ & 45.08 & 3.00 & 7.01 & 7.95 \\
\hline SB2 & $\mathrm{CdL}_{2}$ & $\begin{array}{l}\mathrm{C}_{30} \mathrm{H}_{24} \mathrm{~N}_{4} \mathrm{O}_{4} \mathrm{Br}_{2} \mathrm{Cl}_{2} \mathrm{Cd} \\
(847.41)\end{array}$ & $>300$ & $\begin{array}{l}\text { Lemon } \\
\text { Yellow }\end{array}$ & 42.48 & 2.83 & 6.60 & 13.26 \\
\hline SB3 & $\mathrm{ZnL}_{2}$ & $\begin{array}{l}\mathrm{C}_{30} \mathrm{H}_{24} \mathrm{~N}_{4} \mathrm{O}_{4} \mathrm{Br}_{2} \mathrm{Cl}_{2} \mathrm{Zn} \\
(800.38)\end{array}$ & 270 & $\begin{array}{l}\text { Yellowish } \\
\text { Green }\end{array}$ & 44.97 & 2.99 & 6.99 & 8.16 \\
\hline SB4 & $\mathrm{FeL}_{2}$ & $\begin{array}{l}\mathrm{C}_{30} \mathrm{H}_{24} \mathrm{~N}_{4} \mathrm{O}_{4} \mathrm{Br}_{2} \mathrm{Cl}_{2} \mathrm{Fe} \\
(790.84)\end{array}$ & $>300$ & Light Brown & 45.52 & 3.03 & 7.08 & 7.06 \\
\hline SB5 & $\mathrm{NiL}_{2}$ & $\begin{array}{l}\mathrm{C}_{30} \mathrm{H}_{24} \mathrm{~N}_{4} \mathrm{O}_{4} \mathrm{Br}_{2} \mathrm{Cl}_{2} \mathrm{Ni} \\
\text { (793.69) }\end{array}$ & $>300$ & Yellow & 45.35 & 3.02 & 7.05 & 7.39 \\
\hline SB6 & $\mathrm{SnL}_{2}$ & $\begin{array}{l}\mathrm{C}_{30} \mathrm{H}_{24} \mathrm{~N}_{4} \mathrm{O}_{4} \mathrm{Br}_{2} \mathrm{Cl}_{2} \mathrm{Sn} \\
(853.71)\end{array}$ & $>300$ & Off white & 42.16 & 2.81 & 6.55 & 13.90 \\
\hline SB7 & $\mathrm{CrL}_{2}$ & $\begin{array}{l}\mathrm{C}_{30} \mathrm{H}_{24} \mathrm{~N}_{4} \mathrm{O}_{4} \mathrm{Br}_{2} \mathrm{Cl}_{2} \mathrm{Cr} \\
(787)\end{array}$ & $>300$ & Brown & 45.74 & 3.04 & 7.11 & 6.60 \\
\hline SB8 & $\mathrm{ZrL}_{2}$ & $\begin{array}{l}\mathrm{C}_{30} \mathrm{H}_{24} \mathrm{~N}_{4} \mathrm{O}_{4} \mathrm{Br}_{2} \mathrm{Cl}_{2} \mathrm{Zr} \\
(826.22)\end{array}$ & $>300$ & $\begin{array}{l}\text { Light } \\
\text { Yellow }\end{array}$ & 43.57 & 2.90 & 6.77 & 11.04 \\
\hline
\end{tabular}

Metal complexes were screened for antimalarial, anti-tubercular, and antimicrobial activities.

IR spectra of Schiff base bis-imine ligand (SB) showed a strong band at $1616 \mathrm{~cm}^{-1}$ corresponding to the stretching frequency of the $\mathrm{C}=\mathrm{N}$ group.

The IR spectra of metal complexes show stretching frequency bands in the region $395-462 \mathrm{~cm}^{-1}$ can be recognized for coordination of metal ion and the nitrogen atom of ligand i.e., M-N bands. The IR stretching frequency bands at $500-827 \mathrm{~cm}^{-1}$ were characterized for metal ion, and the oxygen atom of ligand was coordinated (M-O). Frequency bands at 1610$1624 \mathrm{~cm}^{-1}$ indicate the $\mathrm{C}=\mathrm{N}$ group. Frequency bands at $2939-3074 \mathrm{~cm}^{-1}$ can be assigned to $\mathrm{C}$ $\mathrm{H}$ bonds. The Schiff base ligand bis-imine is coordinated with metal ion through phenolic oxygen and azomethine nitrogen. Thus, the ligand behaves as bidentate. 
Table 2. Infrared spectra data of metal complexes.

\begin{tabular}{|c|c|c|c|c|c|}
\hline Sample code & Compound & $v \mathrm{~cm}^{-1}(\mathrm{M}-\mathrm{N})$ & $v \mathrm{~cm}^{-1}(\mathrm{M}-\mathrm{O})$ & $v \mathrm{~cm}^{-1}(\mathrm{C}=\mathrm{N})$ & $\begin{array}{l}v \mathrm{~cm}^{-1} \\
(\mathrm{C}-\mathrm{H})\end{array}$ \\
\hline SB1 & $\mathrm{CuL}_{2}$ & 447 & 507 & 1610 & 3068 \\
\hline SB2 & $\mathrm{CdL}_{2}$ & 395 & 655 & 1624 & 3072 \\
\hline SB3 & $\mathrm{ZnL}_{2}$ & 450 & 555 & 1618 & 2999 \\
\hline SB4 & $\mathrm{FeL}_{2}$ & 447 & 500 & 1620 & 2974 \\
\hline SB5 & $\mathrm{NiL}_{2}$ & 462 & 691 & 1618 & 3072 \\
\hline SB6 & $\mathrm{SnL}_{2}$ & 459 & 646 & 1618 & 3074 \\
\hline SB7 & $\mathrm{CrL}_{2}$ & 405 & 827 & 1612 & 2939 \\
\hline SB8 & $\mathrm{ZrL}_{2}$ & 457 & 648 & 1618 & 2968 \\
\hline
\end{tabular}

In the UV spectra of metal complexes, the wavelength of maximum absorbance $\left(\lambda_{\max }\right)$ ranges from $206.4-230 \mathrm{~nm}$. The $\lambda_{\max }$ value of $\mathrm{Fe}(\mathrm{II})$ is high at higher absorption. The metal complexes were formed in a ligand to metal ratio of $2: 1$.

Table 3. $\lambda_{\max }$ Value of synthesized metal complexes

\begin{tabular}{c|c|c} 
Code no & Compound & Wavelength $\left(\boldsymbol{\lambda}_{\max }\right)$ \\
\hline SB1 & $\mathrm{CuL}_{2}$ & 211.5 \\
\hline SB2 & $\mathrm{CdL}_{2}$ & 213.9 \\
\hline SB3 & $\mathrm{ZnL}_{2}$ & 213.9 \\
\hline SB4 & $\mathrm{FeL}_{2}$ & 230 \\
\hline SB5 & $\mathrm{NiL}_{2}$ & 225.1 \\
\hline SB6 & SnL$_{2}$ & 206.4 \\
\hline SB7 & $\mathrm{CrL}_{2}$ & 225.7 \\
\hline SB8 & $\mathrm{ZrL}_{2}$ & 222.8
\end{tabular}

Antimalarial activity study of the synthesized compounds showed that $\mathrm{Zn}$ (II) metal complex was remarkably active while $\mathrm{Cd}(\mathrm{II}), \mathrm{Fe}(\mathrm{II}), \mathrm{Cr}(\mathrm{II})$, and $\mathrm{Zr}$ (II) were moderately active against Plasmodium falciparum as compared to standard drugs Chloroquine and Quinine.

Table 4. Antimalarial activity.

Minimal Inhibition Concentration

\begin{tabular}{l|l|l}
\multicolumn{3}{c}{ Minimal Inhibition Concentration } \\
\hline Code no. & Compound & MEAN IC50 \\
\hline SB1 & $\mathrm{CuL}_{2}$ & $2.10 \mu \mathrm{g} / \mathrm{ml}$ \\
\hline SB2 & $\mathrm{CdL}_{2}$ & $0.57 \mu \mathrm{g} / \mathrm{ml}$ \\
\hline SB3 & $\mathrm{ZnL}_{2}$ & $0.39 \mu \mathrm{g} / \mathrm{ml}$ \\
\hline SB4 & $\mathrm{FeL}_{2}$ & $0.65 \mu \mathrm{g} / \mathrm{ml}$ \\
\hline SB5 & $\mathrm{NiL}_{2}$ & $1.65 \mu \mathrm{g} / \mathrm{ml}$ \\
\hline SB6 & $\mathrm{SnL}_{2}$ & $2.21 \mu \mathrm{g} / \mathrm{ml}$ \\
\hline SB7 & $\mathrm{CrL}_{2}$ & $0.64 \mu \mathrm{g} / \mathrm{ml}$ \\
\hline SB8 & ZrL 2 & $0.62 \mu \mathrm{g} / \mathrm{ml}$ \\
\hline Standard & Chloroquine & IC $50-0.020 \mu \mathrm{g} / \mathrm{ml}$ \\
\cline { 2 - 3 } & Quinine & IC $50-0.268 \mu \mathrm{g} / \mathrm{ml}$
\end{tabular}

Table 5. Anti-tubercular activity.

\begin{tabular}{l|l|l} 
Method & L. J. Medium [Conventional method] \\
\hline Bacteria & H37Rv & \multicolumn{2}{l}{} \\
\hline Standard Drug & Isoniazid and Rifampicin \\
\hline Code no. & Compound & MIC $\mu \mathrm{g} / \mathrm{ml}$ \\
\hline SB1 & $\mathrm{CuL}_{2}$ & 250 \\
\hline SB2 & $\mathrm{CdL}_{2}$ & 62.5 \\
\hline SB3 & $\mathrm{ZnL}_{2}$ & 50 \\
\hline SB4 & $\mathrm{FeL}_{2}$ & 100 \\
\hline SB5 & $\mathrm{NiL}_{2}$ & 125 \\
\hline SB6 & $\mathrm{SnL}_{2}$ & 250 \\
\hline SB7 & $\mathrm{CrL}_{2}$ & 50 \\
\hline SB8 & ZrL2 & 500 \\
\hline \multirow{2}{*}{ Standard } & Isoniazid & $0.20 \mu \mathrm{g} / \mathrm{ml}$ \\
\cline { 2 - 3 } & & $99 \%$ inhibition \\
\cline { 2 - 3 } & \multirow{2}{*}{ Rifampicin } & $40 \mu \mathrm{g} / \mathrm{ml}$ \\
\cline { 2 - 3 } & & $99 \%$ inhibition
\end{tabular}


Synthesized metal complexes were screened for anti-tubercular activity by using L.J. medium (conventional method). $\mathrm{Cd}$ (II) $\mathrm{Zn}$ (II) and $\mathrm{Cr}$ (II) metal complexes showed activity against mycobacterium tubercular as compared to standard drugs isoniazid and Rifampicin.

The antimicrobial activity studies of synthesized metal complexes reveal that $\mathrm{Cu}(\mathrm{II})$, $\mathrm{Fe}(\mathrm{II}), \mathrm{Ni}(\mathrm{II}), \mathrm{Sn}(\mathrm{II}), \mathrm{Cr}(\mathrm{II})$, and $\mathrm{Zr}(\mathrm{II})$ showed excellent activity against fungus $C$. Albicans (MTCC 227). $\mathrm{Cu}(\mathrm{II}), \mathrm{Ni}(\mathrm{II})$, and $\mathrm{Cr}$ (II) were moderately active against $A$. Niger ( MTCC 282). $\mathrm{Cr}(\mathrm{II})$ and $\mathrm{Zr}$ (II) were active against A. Clavatus ( MTCC 1323) fungal species as compared to standard drug Griseofulvin.

$\mathrm{Cu}(\mathrm{II}), \mathrm{Zn}(\mathrm{II}), \mathrm{Fe}(\mathrm{II}), \mathrm{Sn}(\mathrm{II})$, and $\mathrm{Zr}(\mathrm{II})$ metal complexes showed excellent activity against bacteria E. Coli (MTCC 443). Sn(II), Zn(II), and Fe(II) showed remarkable activity against $P$. Aeruginosa (MTCC 1688). Cu(II), Zn(II), Ni(II), $\mathrm{Sn}(\mathrm{II}), \mathrm{Cr}(\mathrm{II})$, and $\mathrm{Zr}(\mathrm{II})$ showed moderate to excellent activity against $S$. Aureus (MTCC 96). $\mathrm{Cu}(\mathrm{II}), \mathrm{Ni}(\mathrm{II})$, and $\mathrm{Zr}$ (II) showed excellent activity against S. Pyogenus (MTCC 442) bacteria species as compared to standard drug Ampicillin and Chloramphenicol.

Table 6. Antimicrobial activity of the synthesized metal complexes.

\begin{tabular}{|c|c|c|c|c|c|c|c|c|}
\hline \multirow{4}{*}{$\begin{array}{l}\text { Sample } \\
\text { code }\end{array}$} & \multirow[t]{4}{*}{ Compound } & \multicolumn{3}{|c|}{ Antifungal Activity } & \multicolumn{4}{|c|}{ Antibacterial Activity } \\
\hline & & \multicolumn{3}{|c|}{ Minimal Inhibition Concentration } & \multicolumn{4}{|c|}{ Minimal Inhibition Concentration } \\
\hline & & C. A. & A. N. & A. C. & E. C. & P. A. & S. A. & S. P. \\
\hline & & $\begin{array}{l}\text { MTCC } \\
227 \\
\end{array}$ & $\begin{array}{l}\text { MTCC } \\
282\end{array}$ & $\begin{array}{l}\text { MTCC } \\
1323 \\
\end{array}$ & $\begin{array}{l}\text { MTCC } \\
443 \\
\end{array}$ & $\begin{array}{l}\text { MTCC } \\
1688 \\
\end{array}$ & $\begin{array}{l}\text { MTCC } \\
96\end{array}$ & $\begin{array}{l}\text { MTCC } \\
442 \\
\end{array}$ \\
\hline SB1 & $\mathrm{CuL}_{2}$ & 250 & 500 & $>1000$ & 100 & 250 & 250 & 100 \\
\hline SB2 & $\mathrm{CdL}_{2}$ & 1000 & 1000 & $>1000$ & 250 & 500 & 500 & 250 \\
\hline SB3 & $\mathrm{ZnL}_{2}$ & 1000 & $>1000$ & 1000 & 50 & 62.5 & 250 & 500 \\
\hline SB4 & $\mathrm{FeL}_{2}$ & 500 & 1000 & 1000 & 100 & 62.5 & 500 & 250 \\
\hline SB5 & $\mathrm{NiL}_{2}$ & 500 & 500 & 1000 & 250 & 500 & 50 & 100 \\
\hline SB6 & $\mathrm{SnL}_{2}$ & 500 & 1000 & 1000 & 100 & 50 & 250 & 125 \\
\hline SB7 & $\mathrm{CrL}_{2}$ & 250 & 500 & 500 & 125 & 250 & 100 & 125 \\
\hline SB8 & $\mathrm{ZrL}_{2}$ & 500 & 1000 & 500 & 62.5 & 100 & 250 & 25 \\
\hline \multirow{2}{*}{$\begin{array}{l}\text { Standard } \\
\text { Drug }\end{array}$} & Greseofulvin & 500 & 100 & 100 & - & - & - & - \\
\hline & Nystatin & 100 & 100 & 100 & - & - & - & - \\
\hline \multirow{5}{*}{$\begin{array}{l}\text { Standard } \\
\text { Drug }\end{array}$} & Ampicillin & - & - & - & 100 & - & 250 & 100 \\
\hline & Chloramphenicol & - & - & - & 50 & 50 & 50 & 50 \\
\hline & Gentamycin & - & - & - & 0.05 & 1 & 0.25 & 0.5 \\
\hline & Ciprofloxacin & - & - & - & 25 & 25 & 50 & 50 \\
\hline & Norfloxacin & - & - & - & 10 & 10 & 10 & 10 \\
\hline
\end{tabular}

C. A. $=$ C. Albicans, A. N. = A. niger, A. C. = A. clavatus, E. C. = E. coli, $P$. A. = P. aeruginosa, S. A. = S. aureus, S. P. = S. Pyogenus

\section{Conclusions}

In the present work, a new bidentate Schiff base bis-imine ligand was synthesized with 1-(2-bromo, 5-methoxy benzylidene) hydrazine and 5-chlorosalicylaldehyde. The bis-imine ligand was used for the synthesis of metal complexes with metals $\mathrm{Cu}(\mathrm{II}), \mathrm{Cd}(\mathrm{II}), \mathrm{Zn}$ (II), $\mathrm{Fe}$ (II), $\mathrm{Ni}(\mathrm{II}), \mathrm{Sn}(\mathrm{II}), \mathrm{Cr}(\mathrm{II})$, and $\mathrm{Zr}(\mathrm{II})$. The synthesized ligand and metal complexes were characterized by different spectroscopic methods. The synthesized metal complexes were analyzed for antimalarial, anti-tubercular, and antimicrobial activities. The metal complexes $\mathrm{Zn}(\mathrm{II}), \mathrm{Cd}(\mathrm{II}), \mathrm{Fe}(\mathrm{II}), \mathrm{Cr}(\mathrm{II})$, and $\mathrm{Zr}$ (II) were active against malaria as compared to standard drug chloroquine and quinine. Metal complexes $\mathrm{Cd}(\mathrm{II}), \mathrm{Zn}(\mathrm{II})$, and $\mathrm{Cr}$ (II) showed activity against M.TB as compared to standard drug isoniazid and Rifampicin. Metal complexes Cu(II), $\mathrm{Fe}(\mathrm{II}), \mathrm{Sn}(\mathrm{II}), \mathrm{Ni}(\mathrm{II}), \mathrm{Cr}$ (II), and $\mathrm{Zr}$ (II) showed moderate to excellent activity against fungal species as compared to standard drug Griseofulvin. $\mathrm{Cu}(\mathrm{II}), \mathrm{Zn}(\mathrm{II}), \mathrm{Fe}(\mathrm{II}), \mathrm{Sn}(\mathrm{II}), \mathrm{Ni}(\mathrm{II}), \mathrm{Cr}$ (II), and $\mathrm{Zr}$ (II) metal complexes exhibited activity against bacteria species as compared with standard drug Ampicillin and Chloramphenicol. 


\section{Funding}

This research received no external funding.

\section{Acknowledgments}

\section{The authors are thankful to the Principal, Deogiri College, Aurangabad (MS) India, for providing necessary laboratory facilities.}

\section{Conflicts of Interest}

The authors declare no conflict of interest.

\section{References}

1. Manimohan, M.; Pugalmani, S.; Sithique, M.A. Biologically active novel N, N, O donor tridentate water soluble hydrazide based O-carboxymethyl chitosan Schiff base $\mathrm{Cu}$ (II) metal complexes: Synthesis and characterization. International Journal of Biological Macromolecules 2019, 136, 738-754, https://doi.org/10.1016/j.ijbiomac.2019.06.115.

2. Hamil, A.; Khalifa, K.; Almutaleb, A.; Nouradean, M. Synthesis, Characterization and antibacterial activity studies of some transition metal chelates of $\mathrm{Mn}$ (II), Ni (II) and $\mathrm{Cu}$ (II) with Schiff base derived from diacetylmonoxime with O-phenylenediamine. Advanced Journal of Chemistry-Section A 2020, 3, 524-533, https://doi.org/10.33945/SAMI/AJCA.2020.4.13.

3. Bhale, S.P.; Yadav, A.R.; Tekale, S.U.; Nawale, R.B.; Marathe, R.P.; Kendrekar, P.S.; Pawar, R.P. Synthesis, characterization and antimicrobial screening of novel hydrazide ligand \& it's transition metal complexes. Asian Journal of Chemistry 2019, 31, 938-942, https://doi.org/10.14233/ajchem.2019.21795.

4. Tsantis, S.T.; Tzimopoulos, D.I.; Holynska, M.; Perlepes, S.P. Oligonuclear actinoid complexes with Schiff bases as ligands-older achievements and recent progress. International Journal of Molecular Sciences 2020, 21, https://doi.org/10.3390/ijms21020555.

5. Liu, X.; Hamon, J.R. Recent developments in penta, hexa-and heptadentate Schiff base ligands and their metal complexes. Coordination Chemistry Reviews 2019, 389, 94-118, https://doi.org/10.1016/j.ccr.2019.03.010.

6. Gayakwad, D.R.; Sarda, S.R.; Nawale, R.B.; Munde, S.B.; Bharad, J.V.; Kendrekar, P.S. Synthesis and biological activity of novel Schiff base ligand and its transition metal complexes. Current Pharma Research 2019, 9, 3378-3385.

7. Kwon, D.H.; Small, B.L.; Sydora, O.L.; Bischof, S.M.; Ess, D.H. Challenge of using practical DFT to model Fe pendant donor diimine catalyzed ethylene oligomerization. The Journal of Physical Chemistry C 2019, 123, 3727-3739, https://doi.org/10.1021/acs.jpcc.9b00129.

8. Bhale, S.; Tekale, S.U.; Kohire, R.; Phase, R.; Pawar, R. Synthesis, characterization, antimicrobial activity and transition metal complexes of 3-bromo-N'-(1-(5-chloro-2-hydroxyphenyl) ethylidene) benzohydrazide ligand. Current Pharma Research 2019, 9, 3283-3289.

9. Ambhure, R.U.; Mirgane, S.R.; Thombal, D.U.; Nawale, R.B.; Marathe, R.P.; Pawar, R.P. Synthesis and antibacterial study of some Schiff bases complexes. Modern Organic Chemistry Research 2017, 2, 11-16, https://doi.org/10.22606/mocr.2017.21003.

10. Kauthale, S.; Tekale, S.; Damale, M.; Sangshetti, J.; Pawar, R. Synthesis, antioxidant, antifungal, molecular docking and ADMET studies of some thiazolyl hydrazones. Bioorganic \& Medicinal Chemistry Letters 2017, 27, 3891-3896, https://doi.org/10.1016/j.bmcl.2017.06.043.

11. Chitrapriya, N.; Kamatchi, T.S.; Zeller, M.; Lee, H.; Natrajan, K. Synthesis, spectroscopic, crystal structure and DNA binding of $\mathrm{Ru}$ (II) complexes with 2-hydroxy-benzoic acid [1-(4-hydroxy-6-methyl-2-oxo-2Hpyran-3-yl)-ethylidene]-hydrazide. Spectrochimica Acta 2011, 81, 128-134, https://doi.org/10.1016/j.saa.2011.05.069.

12. Raman, N.; Raja, J.D.; Sakhtivel, A. Synthesis, spectral characterization of Schiff base transition metal complexes: DNA cleavage and antimicrobial activity studies. Journal of Chemical Sciences 2007, 119, 303310, https://doi.org/10.1007/s12039-007-0041-5.

13. Maji, A.K. Drug susceptibility testing methods of antimalarial agents. Tropical Parasitology 2018, 8, 70-76, https://dx.doi.org/10.4103\%2F2229-5070.248695.

14. Anamika, G.; Malay, R.S.; Shampa, A. Evaluation of the performance of nitrate reductase assay (NRA) for rapid drug susceptibility testing of M. Tuberculosis in north India. Journal of Health, Population and Nutrition 2011, 29, 20-25, https://doi.org/10.3329/jhpn.v29i1.7563. 